\title{
HUBUNGAN GETARAN LENGAN-TANGAN DENGAN KELUHAN CARPAL TUNNEL SYNDROME PADA PEKERJA HOME INDUSTRY PANDAI BESI DI KECAMATAN SOKOBANAH SAMPANG
}

\author{
Fathul Qoribullah \\ Keselamatan dan Kesehatan Kerja, Universitas Nahdlatul Ulama Surabaya \\ Email: fathul.km14@student.unusa.ac.id
}

\begin{abstract}
Carpal Tunnal Syndrome (CTS) is one of the occupational diseases. CTS is caused by a dysfunction of the median nerve that occurs due to elevated pressure in the carpal tunnel. The research objective is to analyze the correlation between hand-arm vibration complaints Tunnal Carpal Syndrome in workers Home Industry blacksmith in District Sokobanah. Research design withapproach Cross Sectional. The population and samples obtained were all Home Industry blacksmith workers in Sokobanah District with 33 people. The sampling technique using saturated samples is that the population has the same opportunity to be sampled. The variables studied were arm-arm vibration andcomplaints Carpal Tunnal Syndrome. The research instrument used was a questionnaire sheet and a measuring instrument (Vibration Meter). Data analysis usingtest spearman correlation. The results showed that most (75.8\%) were exposed to uncomfortable vibrations, most (63.6\%) had severe CTS complaints and there was a significant relationship between hand arm vibration andcomplaints Carpal Tunnal Syndrome $(p=0.01)$. It is concluded that the higher arm vibration exposure it can raise grievances Tunnal Carpal Syndrome in workers Home Industry blacksmith in District Sokobanah. It is recommended for Home Industries to increase supervision of blacksmith workers through performance evaluation with aspects of prudence in working and using Personal Protective Equipment (PPE) for workers.
\end{abstract}

Keywords: Hand Arm, Carpal Tunnel Syndrome (CTS), Home Industry

\begin{abstract}
ABSTRAK
Carpal Tunnel Syndrome (CTS) adalah salah satu penyakit akibat kerja. CTS disebabkan oleh disfungsi saraf median yang terjadi karena peningkatan tekanan di terowongan karpal. Tujuan penelitian ini adalah untuk menganalisis hubungan antara keluhan getaran lengan-tangan Carpal Tunnel Syndrome di pandai besi Industri Rumah Tangga di Kabupaten Sokobanah. Desain penelitian dengan pendekatan Cross-Sectional. Populasi dan sampel yang diperoleh adalah semua pekerja pandai besi Industri Rumah Tangga di Kabupaten Sokobanah dengan 33 orang. Teknik pengambilan sampel menggunakan sampel jenuh adalah bahwa populasi memiliki kesempatan yang sama untuk dijadikan sampel. Variabel yang diteliti adalah getaran lengan-lengan dan keluhan Carpal Tunnel Syndrome. Instrumen penelitian yang digunakan adalah lembar kuesioner dan alat ukur (Vibration Meter). Analisis data menggunakan uji korelasi Spearman. Hasil penelitian menunjukkan bahwa sebagian besar $(75,8 \%)$ terkena getaran tidak nyaman, sebagian besar $(63,6 \%)$ memiliki keluhan CTS parah dan ada hubungan yang signifikan antara getaran lengan-tangan dan keluhan Carpal Tunnel Syndrome $(\mathrm{p}=0,01)$. Disimpulkan bahwa paparan getaran lengan yang lebih tinggi dapat
\end{abstract}


meningkatkan keluhan Carpal Tunnel Syndrome pada pekerja Home Industri pandai besi di Kabupaten Sokobanah. Direkomendasikan bagi Industri Rumah Tangga untuk meningkatkan pengawasan pekerja pandai besi melalui evaluasi kinerja dengan aspek kehati-hatian dalam bekerja dan menggunakan Alat Pelindung Diri (PPE) untuk pekerja.

Kata kunci: Lengan-Tangan, Carpal Tunnel Syndrome (CTS), Industri Rumahan

\section{PENDAHULUAN}

Berbagai kegiatan yang menggunakan banyak tangan dalam waktu lama sering dikaitkan dengan terjadinya Carpal Tunnel Syndrome (CTS). CTS terkait dengan pekerjaan yang menggunakan kombinasi kekuatan dan pengulangan gerakan panjang pada jari dalam jangka waktu yang lama. ${ }^{1}$ Saat ini, industri informal tidak didukung oleh layanan dan promosi keselamatan dan kesehatan kerja (K3). Selain itu, tidak sesuai dengan desain tempat kerja, prosedur atau organisasi kerja yang buruk, dan kurangnya peralatan pelindung bagi pekerja.

Pekerja sebagai manusia memiliki bagian anggota yang penting dalam tubuh, misalnya, seperti tangan yang merupakan salah satu anggota tubuh manusia yang penting dalam melakukan aktivitas sehari-hari. Tangan manusia berfungsi sebagai alat penyeimbang dan pendukung tubuh. ${ }^{2}$ Sedangkan di masa lalu produksi, produsen bekerja karyawan dengan berbagai pekerjaan yang berbeda seperti memotong, memanen, dan mempertajam semua produksi dilakukan secara manual menggunakan kekuatan lengan-tangan tanpa menggunakan Alat Pelindung Diri (APD) karena dalam sebagian pekerja mengaku menahan dan tidak bisa bergerak bebas untuk melakukan pekerjaan, mengakibatkan pekerjaan yang tidak ergonomis dan dapat menyebabkan gangguan muskuloskeletal karena gerakan berulang-ulang dan getaran panjang.

Carpal Tunnel Syndrome (CTS) tergolong dalam penyakit akibat kerja. CTS disebabkan oleh kerusakan saraf yang terjadi disebabkan oleh peningkatan tekanan di tunnel carpal. Gejala yang dialami penderita diantaranya yaitu nyeri, kesemutan, mati rasa atau terasa seperti tertusuk ketika pulih dari kesemutan dalam sebaran saraf median tangan. Hal itu biasanya terjadi pada jari telunjuk jari tengah dan bagian radial dari jari manis. Jika aktivitas ini dilakukan secara terus-menerus menuai kesinambungan jangka panjang dari getaran besi yang cukup tinggi itu akan menekan saraf yang ada di daerah pergelangan tangan (saraf median).

Kejadian CTS yang terjadi akibat bekerja, sesegera mungkin diatasi sebelum terlambat karena rasa sakit di tangan akan lebih sering terjadi sehingga dapat mengurangi produktivitas di tempat kerja. Jika tidak segera dalam penanganan atau perawatan, hal itu dapat menyebabkan kecacatan pada jari pekerja. Selain menyebabkan rasa sakit, juga dapat mengurangi fungsi tangan dan pergelangan tangan sehingga berefek pada pekerjaan. ${ }^{3}$ 
Beberapa cara untuk mengurangi keluhan CTS akibat bekerja adalah dengan melakukan kegiatan pijatan secara mandiri dan jika perlu dengan melakukan terapi langsung dilakukan di rumah. Selain itu, sediakan pendidikan atau pelatihan tentang cara bekerja dengan aman menggunakan Alat Pelindung Diri (APD), baik sebelum bekerja atau saat melakukan pekerjaan.

Oleh karena itu, perlu dilakukan identifikasi getaran lengan-lengan dengan penyakit Carpal Tunnel Syndrome pada pekerja pandai besi industri rumah, sehingga nantinya bisa memberikan pengetahuan dan pencegahan kepada pekerja sehingga mereka bisa menggunakan alat pelindung diri untuk melakukan pekerjaannya.

\section{METODE PENELITIAN}

Penelitian ini menggunakan desain analitik yang merupakan studi cross-sectional untuk mempelajari dinamika korelasi antara getaran lengan-lengan dan keluhan dari Carpal Tunnel Syndrome. Populasi dari penelitian ini adalah semua pekerja rumah tangga pandai besi industri di Kecamatan Sokobanah Sampang.

Dalam penelitian ini, sampel yang digunakan adalah sampling jenuh, yaitu semua pekerja sebanyak 33 sampel. Dimana sifat pengambilan sampel jenuh, populasi memiliki kesempatan yang sama untuk dijadikan sampel. Lokasi penelitian ini dilakukan pada semua industri rumah tangga pekerja di Kecamatan Sokobanah Sampang. Instrumen dalam penelitian ini adalah kuesioner dan pengukuran getaran lengan menggunakan alat pengukur getaran, dengan pengukuran dilakukan langsung ke pekerja dan alat yang digunakan di tempat kerja.

Pemrosesan data yang diperoleh dilakukan dengan mengedit, penilaian, pengkodean dan tabulasi, menggunakan uji statistik Korelasi Spearman.

\section{HASIL DAN PEMBAHASAN}

\section{Hasil}

\section{Lengan-Tangan}

Getaran didefinisikan sebagai gerakan bolak-balik yang berada di sekitar titik keseimbangan. Kuat lemahnya Gerakan bolakbalik dipengaruhi oleh ukuran energi yang diberikan. Ukuran satu getaran frekuensi adalah satu gerakan bolak penuh. Getaran adalah efek dari sumber yang menggunakan unit hertz. ${ }^{4}$

Tabel di bawah menggambarkan paparan getaran pekerja pandai besi di Kecamatan Sokobanah, Kabupaten Sampang:

Table 1. Distribusi Frekuensi Paparan Getaran Responden Di Kabupaten Sokobanah Kabupaten Sampang

\begin{tabular}{rlrr}
\hline No. & $\begin{array}{c}\text { Paparan } \\
\text { terhadap Getaran }\end{array}$ & $\mathrm{n}$ & \multicolumn{1}{c}{$\%$} \\
\hline 1. & Nyaman & 8 & 24,2 \\
2. & Tidak Nyaman & 25 & 75,8 \\
\hline & Total & 33 & 100,0 \\
\hline
\end{tabular}

Berdasarkan Tabel 1. dapat dilihat bahwa sebagian besar $(75,8 \%)$ responden merasa tidak nyaman. 


\section{Carpal Tunnel Syndrome (CTS)}

Deskripsi distribusi frekuensi responden berdasarkan status kejadian CTS di Kecamatan Sokobanah, Kabupaten Sampang dengan melihat tabel data sebagai berikut:

Tabel 2. Distribusi Frekuensi Keluhan CTS Yang Terjadi Pada Responden di Kabupaten Sokobanah, Kabupaten Sampang

\begin{tabular}{clrr}
\hline No. & \multicolumn{1}{c}{ Keluhan CTS } & \multicolumn{1}{c}{ n } & \multicolumn{1}{c}{$\%$} \\
\hline 1. & Keluhan moderat & 11 & 33,3 \\
2. & Keluhan parah & 21 & 63,6 \\
3. & Keluhan Sangat berat & 1 & 3.0 \\
\hline \multicolumn{2}{c}{ Total } & 33 & 100.0 \\
\hline
\end{tabular}

Data dalam Tabel 2. menunjukkan bahwa keluhan kejadian CTS yang dialami oleh responden, sebagian besar $(63,6 \%)$ mengalami keluhan parah. Dan sisanya mengalami keluhan moderat $(33,3 \%)$ serta keluhan sangat berat $(3,0 \%)$

\section{Korelasi Getaran Lengan-tangan dengan Keluhan Carpal Tunnel Syndrome (CTS)}

Korelasi paparan getaran dengan kejadian keluhan CTS kepada pekerja pandai besi di Kabupaten Sokobanah, Kabupaten Sampang, dapat dilihat pada tabel berikut:

Tabel 3. Korelasi Dengan Keluhan Paparan Getaran CTS Pada Responden di Kabupaten Sokobanah Sampang

\begin{tabular}{|c|c|c|c|c|c|c|c|c|}
\hline \multirow[t]{3}{*}{ Getaran } & \multicolumn{6}{|c|}{ Keluhan CTS } & \multicolumn{2}{|c|}{ Total } \\
\hline & \multicolumn{2}{|c|}{$\begin{array}{l}\text { Keluhan } \\
\text { Moderat }\end{array}$} & \multicolumn{2}{|c|}{ Keluhan Berat } & \multicolumn{2}{|c|}{$\begin{array}{c}\text { Keluhan Sangat } \\
\text { Berat }\end{array}$} & \multirow[b]{2}{*}{$\mathrm{n}$} & \multirow[b]{2}{*}{$\%$} \\
\hline & $\mathrm{n}$ & $\%$ & $\mathrm{n}$ & $\%$ & $\mathrm{n}$ & $\%$ & & \\
\hline Nyaman & 8 & 100,0 & 0 & 0,0 & 0 & 0,0 & 8 & 100,0 \\
\hline Tidak Nyaman & 3 & 12,0 & 21 & 84,0 & 1 & 4,0 & 25 & 100,0 \\
\hline Total & 11 & 33,3 & 21 & 63,6 & 1 & 3,0 & 33 & 100,0 \\
\hline & & elatio & $\begin{array}{l}\text { Spearn } \\
\text { oefficie }\end{array}$ & $\begin{array}{l}\text { Rank: } \\
0.778\end{array}$ & $.01(<0$ & & & \\
\hline
\end{tabular}

Berdasarkan Tabel 3. ditemukan bahwa dari 33 responden, 8 responden mengalami getaran yang nyaman dan semua (100\%) mengalami keluhan CTS sedang. Sementara itu, 25 responden mengalami ketidaknyamanan getaran dan hampir semua $(84 \%)$ memiliki keluhan CTS yang berat.

Berdasarkan uji statistic menggunakan korelasi Spearman rank, diketahui signifikansi atau nilai sig (2-tailed) sebesar 0,01 $(<0,05)$, maka $\mathrm{H}^{0}$ telah ditolak atau $\mathrm{H}^{1}$ diterima, artinya terdapat hubungan yang signifikan antara getaran lengan-tangan dengan keluhan terjadinya Carpal Tunnel Syndrome (CTS) pada pekerja pandai besi di Sokobanah Kabupaten Sampang. Sementara itu, nilai koefisien korelasi yang diperoleh adalah 0,778 yang berarti getaran lengan-tangan dan keluhan-keluhan dari Carpal Tunnel Syndrome memiliki kekuatan hubungan yang kuat. 


\section{Pembahasan}

\section{Lengan-Tangan}

Getaran adalah gerakan bolak-balik yang berada di sekitar titik keseimbangan di mana kekuatan lemahnya dipengaruhi oleh ukuran energi yang diberikan. Dan getaran itu sendiri memiliki amplitudo yang sama (jarak terjauh dari titik tengah).

Berdasarkan hasil studi dari getaran lengan, sebagian besar $(75,8 \%)$ dari responden terkena getaran lengan yang tidak nyaman dari 25 responden. Dalam hal ini, dapat dilihat dari intensitas getaran dari peralatan yang digunakan melebihi Nilai Ambang Batas (NAB) yang ditentukan dengan lama paparan 8 jam per hari, seperti yang tercantum dalam Permenaker No. Per.13/MEN/X/2011 tentang NAV faktor risiko dan kimia di tempat kerja, menyebutkan bahwa NAB getaran peralatan kerja yang memiliki kontak langsung atau tidak langsung pada lengan pekerja ditetapkan pada $4 \mathrm{~m} /$ detik 2, untuk jumlah paparan per hari kerja yang adalah 4 jam dan kurang dari 8 jam.

Ini bisa disebabkan oleh tingkat kerumitan dan ketebalan besi yang dialami oleh setiap pekerja atau target produksi yang harus dipenuhi setiap hari atau setiap minggu. Selain itu, ketika bekerja, beberapa pekerja menggunakan kekuatan tangan mereka untuk mendukung perangkat sehingga dapat bekerja dengan baik, sehingga getaran tidak dapat dihindari. Bahkan pekerjaan itu dilakukan terus menerus. Jika ini terus berlanjut dan waktu yang digunakan untuk istirahat tidak dapat digunakan dengan benar, risiko kerusakan jaringan akan meningkat. ${ }^{5}$

Ini didukung oleh penelitian Lubis tahun 2017 bahwa pekerja menggunakan alat yang akan bergetar dan getaran akan diteruskan ke lengan tangan. ${ }^{6}$ Getaran yang dihasilkan oleh operasional alat kerja dalam jangka waktu singkat tidak akan memiliki efek atau efek pada tangan, tetapi untuk waktu yang lama menyebabkan kelainan atau masalah kesehatan di tangan pekerja.

\section{Keluhan Carpal Tunnel Syndrome}

Carpal Tunnel Syndrome adalah kelainan yang terjadi karena kompresi saraf median di terowongan karpal dengan gejala utama seperti kesemutan dan nyeri yang menjalar ke jari-jari dan tangan yang dipersarafi oleh median saraf, disertai mati rasa, kelemahan otot, kekuatan dan kemungkinan atrofi otot. ${ }^{7}$

Keluhan CTS dapat timbul karena mereka dipengaruhi oleh faktor intrinsik, yaitu faktor dari dalam pekerja, seperti jenis kelamin dan usia. Berdasarkan hasil penelitian, terdapat responden dengan keluhan CTS bahwa semua (100\%) jenis kelamin laki-laki bukan pekerja perempuan, karena pekerjaan pandai besi umumnya membutuhkan tenaga dan kekuatan sehingga hanya pekerja laki-laki.

Lebih lanjut, usia kerja produktif yang berlaku di Indonesia adalah 15-64 tahun. Sedangkan dalam penelitian ini pekerja pandai besi termuda berusia 32 tahun dan tertua 44 tahun. Studi ini menemukan responden dengan 
keluhan CTS pada kelompok umur 25-34 tahun sebanyak 12 orang dan pada kelompok 35-44 tahun sebanyak 21 orang. Sebagian besar responden dengan keluhan CTS ditemukan pada kelompok usia 35-44 tahun. Hal ini dapat dipengaruhi oleh kemampuan fisik yang dimiliki oleh pekerja pada usia itu yang lebih cepat merasa lelah di tangan. Semakin bertambah usia, seseorang akan mengalami degenerasi dalam bentuk jaringan yang rusak, jaringan berganti menjadi jaringan parut, berkurangnya cairan sinovial yang menyebabkan berkurangnya stabilitas otot dan tulang. ${ }^{8}$

Ini juga didukung oleh hasil penelitian Lubis, bahwa usia 29-62 tahun dapat meningkatkan risiko CTS karena terpapar alat kerja tangan lama dan penggunaan sehari-hari di tempat kerja sedangkan kemampuan elastisitas otot-tulang, berkurang sebagai peredam getaran yang disebarkan ke tubuh. ${ }^{6} \mathrm{CTS}$ adalah masalah kesehatan yang muncul untuk waktu yang lama yang akan terjadi pada usia paruh baya dan tua. Dengan bertambahnya usia, dapat dipastikan bahwa paparan getaran dengan alat-alat tangan pada saat bekerja semakin lama juga, kemampuan elastisitas tulang, otot atau tendon semakin menurun.

Risiko CTS juga dapat terjadi pada jenis pekerjaan yang membutuhkan kekuatan atau kekuatan di tangan karena tekanan langsung pada jaringan otot lunak, seperti jenis pekerjaan penyadapan. Hal ini didukung oleh hasil penelitian yang dilakukan oleh Mallapiang \&
Wahyudi tahun 2015 bahwa jenis pekerjaan menyadap atau menahan yang dilakukan secara terus-menerus saat melakukan pekerjaan adalah faktor risiko untuk kejadian CTS. ${ }^{9}$

Keluhan CTS juga dapat disebabkan oleh lingkungan kerja yang tidak memenuhi persyaratan, sikap kerja yang tidak wajar, peralatan dan fasilitas kerja yang tidak sesuai dengan penggunaannya, merupakan masalah yang sering muncul. Masalah ini selain memberikan beban tambahan, juga menyebabkan gangguan otot rangka (musculoskeletal), keluhan subyektif dan kelelahan. ${ }^{10}$

Korelasi Getaran Lengan-Tangan dengan Keluhan Carpal Tunnel Syndrome Berdasarkan Hasil Uji Statistik

Berdasarkan hasil uji statistik ditemukan bahwa ada hubungan yang signifikan antara getaran lengan dan keluhan CTS pada pekerja pandai besi di Kecamatan Sokobanah, Sampang. Semakin sering pekerja terkena getaran, semakin banyak keluhan yang dirasakan. CTS (Carpal Tunnel Syndrome), yang merupakan penekanan yang terjadi pada saraf tengah yang terletak di pergelangan tangan dikelilingi oleh jaringan dan tulang. Penekanan ini disebabkan oleh pembengkakan dan iritasi pada tendon dan lapisan tendon. Biasanya ditandai dengan gejala seperti rasa sakit di pergelangan tangan, merasa tidak nyaman di jari dan mati rasa atau mati rasa. CTS dapat menyebabkan kesulitan dalam memegang sesuatu di tangannya. 
Berdasarkan hasil studi dari getaran lengan, sebagian besar $(75,8 \%)$ dari responden terkena getaran lengan yang tidak nyaman dari 25 responden. Ini berarti bahwa semakin tinggi atau lebih besar getaran senjata yang dialami oleh pekerja, semakin parah keluhan atau tingkat terjadinya CTS pada pekerja pandai besi di Sokobanah Kabupaten Sampang.

Hasil penelitian ini sejalan dengan hasil penelitian yang dilakukan oleh Dinas pada pekerja dari perusahaan pandai besi di Indonesia, yang melaporkan bahwasannya prevalensi CTS untuk pekerja sebesar $28 \%$. Silverstein dan peneliti lain melaporkan pula bahwa terdapat hubungan positif antara keluhan dan gejala CTS dengan faktor kecepatan menggunakan alat, faktor kekuatan gerakan dan getaran di tangan.

Penelitian ini sejalan dengan sebuah penelitian yang telah dilakukan oleh Miranda tahun 2017, yang menyatakan bahwa telah adanya hubungan antara intensitas getaran mesin dengan gejala CTS. Hasil pengukuran pada pekerja operator alat berat yang mengalami gejala CTS sebanyak 92\% melebihi NAB dengan rata-rata lama paparan 8 jam per hari. ${ }^{11}$

Hasil penelitian ini didukung pula oleh penelitian yang telah dilakukan Pangestuti \& Widajati tahun 2014, bahwa terdapat hubungan yang kuat antara intensitas getaran mesin penggiling dan keluhan CTS pada Pekerja Gerinda di PT. DOK dan Pengiriman Surabaya. $^{12}$

\section{SIMPULAN DAN SARAN}

\section{Simpulan}

Berdasarkan hasil penelitian yang telah dilakukan, dapat disimpulkan karena sebagian besar pekerja pandai besi di Kecamatan Sokobanah merasakan paparan getaran yang tidak nyaman, sebagian besar pekerja pandai besi di Kecamatan Sokobanah mengalami CTS dengan keluhan berat, terdapat korelasi yang signifikan. antara getaran lengan dan CTS di Kabupaten Sokobanah.

\section{Saran}

Direkomendasikan bagi Industri Rumah Tangga untuk meningkatkan pengawasan pekerja pandai besi melalui evaluasi kinerja dengan aspek kehati-hatian dalam bekerja dan menggunakan Alat Pelindung Diri (PPE) untuk pekerja.

\section{REFERENSI}

1. Suherman, B., Beberapa faktor yang terkait dengan ventilasi kaki kerja Carpal Tunnel Syndrome (CTS) di Computer Rental Officers di Desa Kahuripan Kota Tasikmalaya. Universitas Siliwangi. 2012.

2. Galih, Eksperimen Komparasi Prosthetic Tangan Berdasarkan Pengaruh Desain Metacarpal Dan Phalanx Phalangeal. Jurnal: Surakarta: Teknik Industri, Universitas Sebelas Maret. 2015.

3. Annisa, Gambaran Risiko Kejadian Carpal Tunnel Syndrome (CTS) pada pekerja wanita di pt. bogatama marinusa 2014.

4. Rokhman, T. Analisis Getaran Pada Footrest Sepeda Motor Tipe Matic dan NonMatic. Jurnal Imiah Teknik Mesin, Vol. 4, No.2 Agustus 2016 Universitas Islam 45 Bekasi. 2016. 
5. Putri, A.K., Hubungan Intensitas Nyeri Dengan Disabilitas Aktivitas Sehari-Hari pada Penderita Carpal Tunnel Syndrome di Rsud Dr. Moewardi di Surakarta. Skripsi. Surakarta: Fakultas Kedokteran Universitas Surakarta. 2014.

6. Lubis, A.A., Andriane, Y., Dewi, M.K., Karakteristik Pasien CTS (Carpal Tunnel Syndrome) di Rumah Sakit Al-Islam Bandung Periode 1 Januari 2011 - 31 Desember 2015. Vol 2, No 1, Prosiding Pendidikan Dokter. 2016.

7. Nissa, P. C., Widjasena, B., Masyarakat, F. K., \& Diponegoro, U. Hubungan Gerakan Repetitif Dan Lama Kerja Dengan Keluhan Carpal Tunnel Syndrome Pada Mahasiswa Teknik Arsitektur. Jurnal Kesehatan Masyarakat, 3(3), 563-571. 2015.

8. Tarwaka. Ergonomi Industri: Dasar-dasar Pengetahuan dan Aplikasi Ergonomi di Tempat Kerja. Edisi Revisi II ed. Surakarta: Harapan Press. 2015.

9. Mallapiang, F. dan Wahyudi, A.A., "Gambaran Faktor Pekerjaan dengan Kejadian Carpal Tunnel Syndrome ( CTS ) pada Pengrajin Batu Tatakan di Desa Lempang Kec. Tanete Riaja Kabupaten Barru Tahun 2015," Public Health Science Journal, 6(2), hal. 19-25. 2015

10. Tarwaka. Ergonomi Industri: Dasar-dasar Pengetahuan dan Aplikasi Ergonomis di
Tempat Kerja. Surakarta: Harapan Press. 2011.

11. Hakim, A.L. Hubungan tingkat keparahan gejala dan status fungsional pada pasien carpal tunnel syndrome diukur menggunakan carpal tunnel syndrome assessment. Jurnal Kedokteran Diponegoro. 5(3). 2016.

12. Pangestuti A.A, dan Widajati N. Faktorfaktor yang Menyebabkan Terjadinya Kecelakaan Kerja di PT.DOK dan Perkapalan Surabaya (Persero). The Indonesian Journal of Occupational Safety and Health. Vol.3, No.1:15. 2014.

13. Wahjoetomo. Peruguruan Tinggi Future Alternative Islamic Boarding Schools, Gema Insani Press: Jakarta. 1997.

14. Hossain M., A knowledge study, attitude and practice about personal hygiene and disease awareness of East West University. Dhaka City. 2012.

15. Permenaker No. Per.13 / MEN / X / 2011 mengenai Nilai Ambang Batas Faktor Fisik dan Faktor Kimia di Tempat Kerja

16. RI Health Department. Program pemberantasan nyamuk. Jakarta. 2016.

17. National Institute of Occupational Safety and Health (NIOSH). Department of Health and Human Services. Cumulative Trauma Disorders in The Workplace. 1995. 